Supporting Information for

\title{
Bright Luminescent Carbon Dots for Multifunctional Selective Sensing and Imaging
}

\section{Applications in Living Cells}

Natesan Thirumalaivasan, ${ }^{\text {a }}$ Shu-Pao $\mathrm{Wu}^{\square, \mathrm{a}}$

aDepartment of Applied Chemistry, National Chiao Tung University, Hsinchu 300, Taiwan.

*Corresponding author, e-mail: spwu@mail.nctu.edu.tw

\section{Contents}

1. Materials and instrumentation

2. Toxicity of Luminescence CDs

3. Table S1 Quantum yield calculation of CDs.

4. Table S2 Stern-Volmer constants (KSV) of different metal ions.

5. Figure S1 CDs surface charge analysis by Zeta potential profile.

6. Figure S2 (a) UV- vis absorbance spectra of CDs in the presence of $150 \mu \mathrm{M}$ of nerve mimic agents in chloroform solution. (b) triphosgene $0-150 \mu \mathrm{M}$. (c) The linear calibration plot of CDs in the presence of triphosgene $(30-90 \mu \mathrm{M})$.

7. Figure S3 UV-vis absorption spectral changes of CDs in the presence of various a) $100 \mu \mathrm{M}$ of various metal ions in DI. $\mathrm{H}_{2} \mathrm{O}$. b) $\mathrm{CD}-\mathrm{Ag}^{+}$complex with $100 \mu \mathrm{M}$ of different amino acids.

8. Figure $\mathbf{S 4} \mathrm{UV}$-vis absorbance titration spectra of CDs upon addition of a) $\mathrm{Ag}^{+}$ions $1-100 \mu \mathrm{M}$. b) $\mathrm{CD}-\mathrm{Ag}^{+}$complex with various concentrations of cystine $1-100 \mu \mathrm{M}$.

9. Figure S5 Linear calibration plot of CDs with (a) $\mathrm{Ag}+$ ions and (b) $\mathrm{CD}-\mathrm{Ag}+$ complex with various concentrations of Cys.

10. Figure S6 Reaction time profile of CDs with a) triphosgene $0-150 \mu \mathrm{M}$. b) $\mathrm{Ag}^{+}$ions 1-100 $\mu \mathrm{M}$. and c) $\mathrm{CD}-\mathrm{Ag}^{+}$complex with various concentrations of cystine 1-100 $\mu \mathrm{M}$.

11. Figure S7 Stern-Volmer plot of CDs in presence of various concentration of $\mathrm{Ag}^{+}$at $\lambda_{\text {em }}=530$ $\mathrm{nm}$.

12. Figure S8 Cellular toxicity of CDs on HCT-116 and HeLa cells. 


\section{Materials and instrumentation}

Chloroform, ethanol, 4-bromoaniline, ethylenediamine, minimum essential media (MEM) and Dulbecco's Modified Eagle's Medium (DMEM) were obtained from commercial sources (CECHO, Sigma Aldrich) and used without further purification. All metal ions, phosgene and mimic nervous agents and amino acid stock solutions and diluting solutions were prepared by the analytical procedure. UV-vis absorption and fluorescence spectra were recorded using UVVisible spectrometer (Agilent 8453), Hitachi F-4500 spectrometer, respectively. Size distribution analysis of CDs was estimated using DLS zeta potential analyzer (zetasizer nano zs90). Fouriertransform infrared (FTIR) spectra of CDs were collected through Bomem DA8.3 FourierTransform Infrared Spectrometer. High-resolution transmission electron microscope (HR-TEM) image was carried out on a transmission electron microscope (JEOL JEM-2010). X-ray photoelectron spectroscopy (XPS) analysis was recorded using a Thermo Fisher Scientific, ESCALAB Xi ${ }^{+}$. Malvern Nanosizer was used to optimize the zeta potentials of CDs. Bioimaging was carried out using a confocal fluorescence microscope (Leica TCS SP5X AOBS).

\section{Toxicity of Luminescence CDs}

The cellular toxicity of CDs was assessed with human colon cancer cell line HCT-116 and cervical cancer line HeLa by MTT (3-(4,5-dimethylthiazol-2-yl)-2,5-diphenyltetrazolium bromide) assay dye. Typically, the cells (1x $10^{5}$ per $\left.\mathrm{mL}\right)$ were seeded in a 96 -well plate for overnight. HCT-116 and HeLa cells were incubated with several concentrations of (200-1000 $\mu \mathrm{g}$ $/ \mathrm{mL})$ CDs for further $24 \mathrm{~h}$. Excess CDs was removed and $20 \mu \mathrm{L}$ of MTT $(5.0 \mathrm{mg} / \mathrm{mL}$ in PBS) was added to each well and then incubated at $37^{\circ} \mathrm{C}$ for 4 hours. $200 \mu \mathrm{L}$ DMSO was added to the growth medium to dissolve the MTT dye. Finally, the absorbance of each well at $570 \mathrm{~nm}$ was recorded by a Multiskan GO microplate reader. The cell toxicity was assessed by the equation below. Cell viability $(\%)=$ (mean absorbance of treatment group)/ (mean absorbance of control group)

Table S1 Quantum yield calculation of CDs.

\begin{tabular}{|l|l|c|c|c|}
\hline \multicolumn{1}{|c|}{ Samples } & \multicolumn{1}{|c|}{ Solvent } & Absorbance & Area & $\begin{array}{c}\text { Percentage of } \\
\text { Quantum yield } \\
(\boldsymbol{\Phi})\end{array}$ \\
\hline Fluorescein & $0.1 \mathrm{M} \mathrm{NaOH}$ & 0.029 & 384037.10 & 95 \\
\hline $\mathbf{C D}$ & $\mathrm{CHCl}_{3}$ & 0.18 & 731137.58 & 32.86 \\
\hline $\mathbf{C D}$ & $\mathrm{H}_{2} \mathrm{O}$ & 0.09 & 150403.9475 & 11.31 \\
\hline $\mathbf{C D}+\mathbf{P h o s g e n e}$ & $\mathrm{CHCl}_{3}$ & 0.364 & 198550.075 & 3.73 \\
\hline $\mathbf{C D}+\mathbf{A g}^{+}$ & $\mathrm{H}_{2} \mathrm{O}$ & 0.45 & 47884.3225 & 0.72 \\
\hline $\mathbf{( C D - \mathbf { A g } ^ { + } + \mathbf { C y s }}$ & $\mathrm{H}_{2} \mathrm{O}$ & 0.097 & 182191.64 & 12.71 \\
\hline
\end{tabular}


Table S2 Stern-Volmer constants $\left(\mathrm{K}_{\mathrm{SV}}\right)$ of different metal ions.

\begin{tabular}{|c|c|}
\hline Metal ions & $\mathrm{K}_{\mathrm{SV}}\left(\mathrm{M}^{-1}\right)^{\mathrm{b}}$ \\
\hline $\mathrm{Ag}^{+}$ & $2.03 \times 10^{4}$ \\
\hline $\mathrm{Al}^{3+}$ & $6.59 \times 10^{2}$ \\
\hline $\mathrm{Ca}^{2+}$ & $22.19 \times 10^{2}$ \\
\hline $\mathrm{Co}^{2+}$ & $19.05 \times 10^{2}$ \\
\hline $\mathrm{Cr}^{3+}$ & $1.85 \times 10^{3}$ \\
\hline $\mathrm{Cu}^{2+}$ & $1.88 \times 10^{3}$ \\
\hline $\mathrm{Fe}^{2+}$ & $1.29 \times 10^{3}$ \\
\hline $\mathrm{Fe}^{3+}$ & $1.29 \times 10^{3}$ \\
\hline $\mathrm{Hg}^{2+}$ & $1.53 \times 10^{2}$ \\
\hline $\mathrm{K}^{2+}$ & $9.85 \times 10^{2}$ \\
\hline $\mathrm{Mg}^{2+}$ & $9.59 \times 10^{2}$ \\
\hline $\mathrm{Mn}^{2+}$ & $1.35 \times 10^{3}$ \\
\hline $\mathrm{Na}^{2+}$ & $1.06 \times 10^{3}$ \\
\hline $\mathrm{Ni}^{2+}$ & $1.01 \times 10^{3}$ \\
\hline $\mathrm{Pb}^{2+}$ & $9.94 \times 10^{2}$ \\
\hline $\mathrm{Zn}^{2+}$ & $1 \times 10^{3}$ \\
\hline
\end{tabular}

${ }^{\mathrm{a}}$ All the metal ions were taken $100 \mu \mathrm{M}$ in DI. $\mathrm{H}_{2} \mathrm{O} \cdot{ }^{\mathrm{b}} \mathrm{K}_{\mathrm{sv}}=[(\mathrm{Io} / \mathrm{I}-1)] / \mathrm{Q}$. where, $\mathrm{I}_{0}=\mathrm{CDs}$ emission intensity, $\mathrm{I}=\mathrm{CDs}$ emission intensity changes with various metal ions. $\mathrm{Q}=$ is the quencher concentration. 

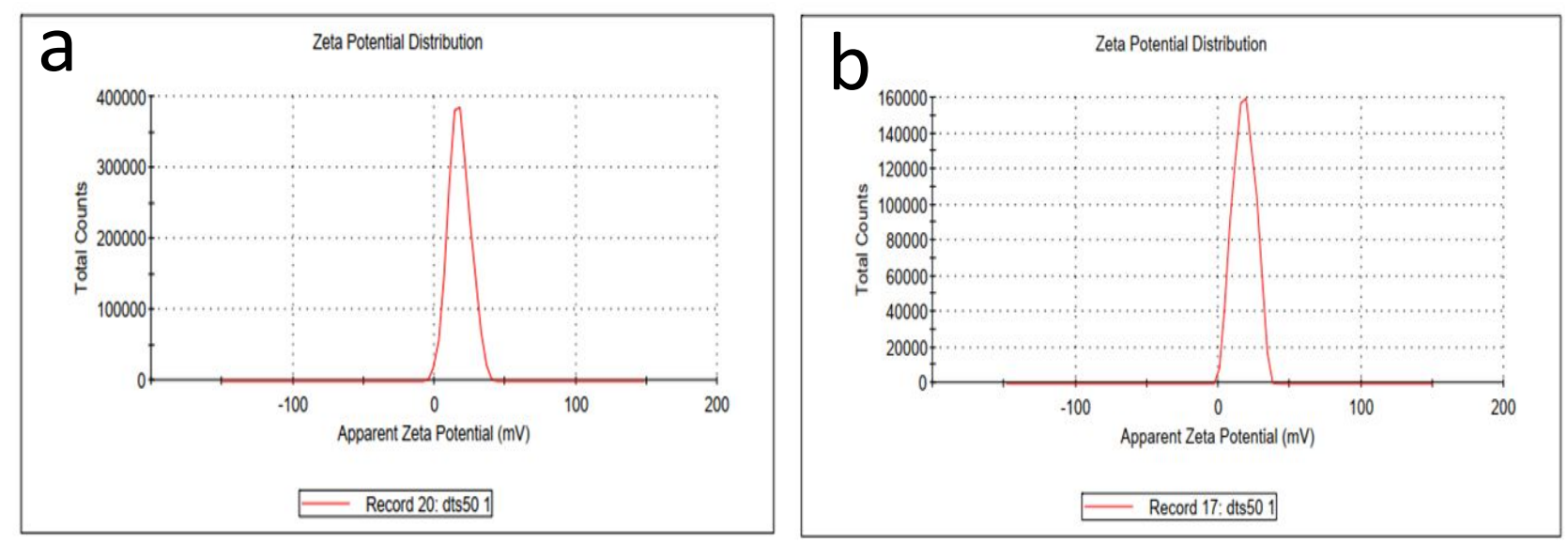

Figure S1 CDs surface charge analysis by Zeta potential profile. 

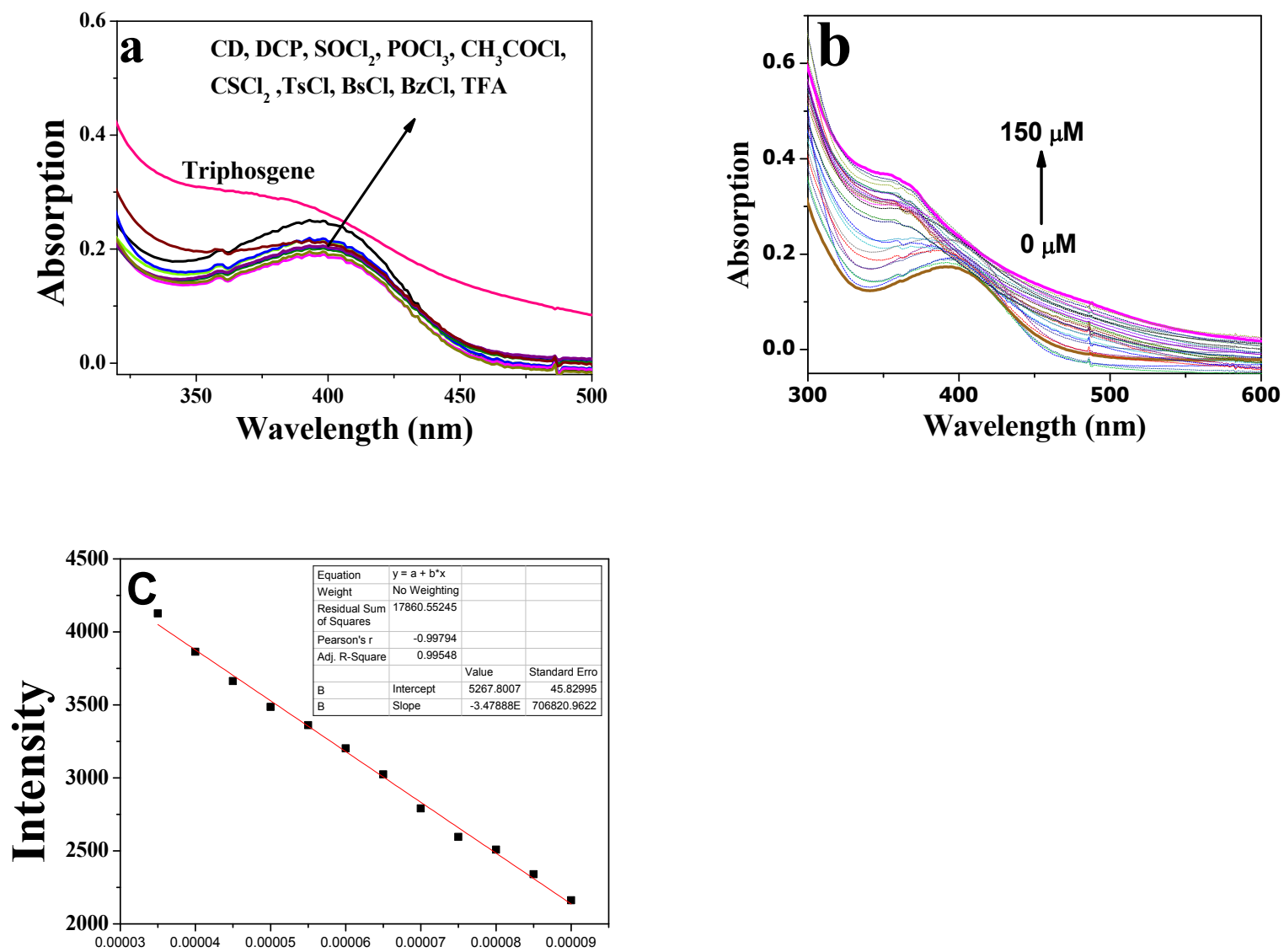

\section{Triphosgene (M)}

LOD calculation for triphosgene

$$
\begin{aligned}
\mathrm{LOD} & =3 \times 0.9487 /\left(3.4788 \times 10^{7}\right) \\
& =81 \mathrm{nM}
\end{aligned}
$$

Figure S2 (a) UV- vis absorbance spectra of CDs in the presence of $150 \mu \mathrm{M}$ of nerve mimic agents in chloroform solution. (b) triphosgene $0-150 \mu \mathrm{M}$. (c) The linear calibration plot of CDs in the presence of triphosgene $(30-90 \mu \mathrm{M})$. 

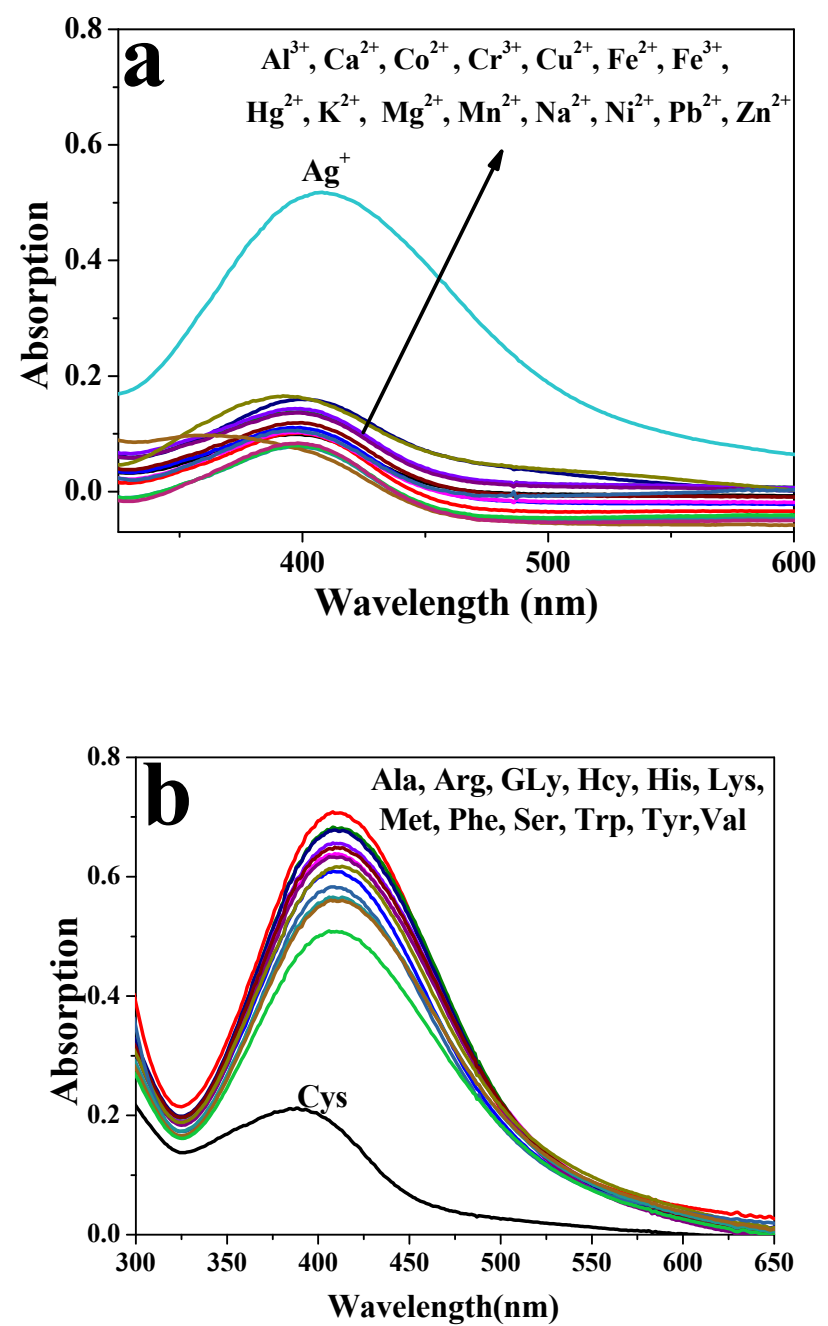

Figure S3 UV-vis absorption spectral changes of CDs in the presence of various a) $100 \mu \mathrm{M}$ of various metal ions in DI. $\mathrm{H}_{2} \mathrm{O}$. b) $\mathrm{CD}-\mathrm{Ag}^{+}$complex with $100 \mu \mathrm{M}$ of different amino acids. 

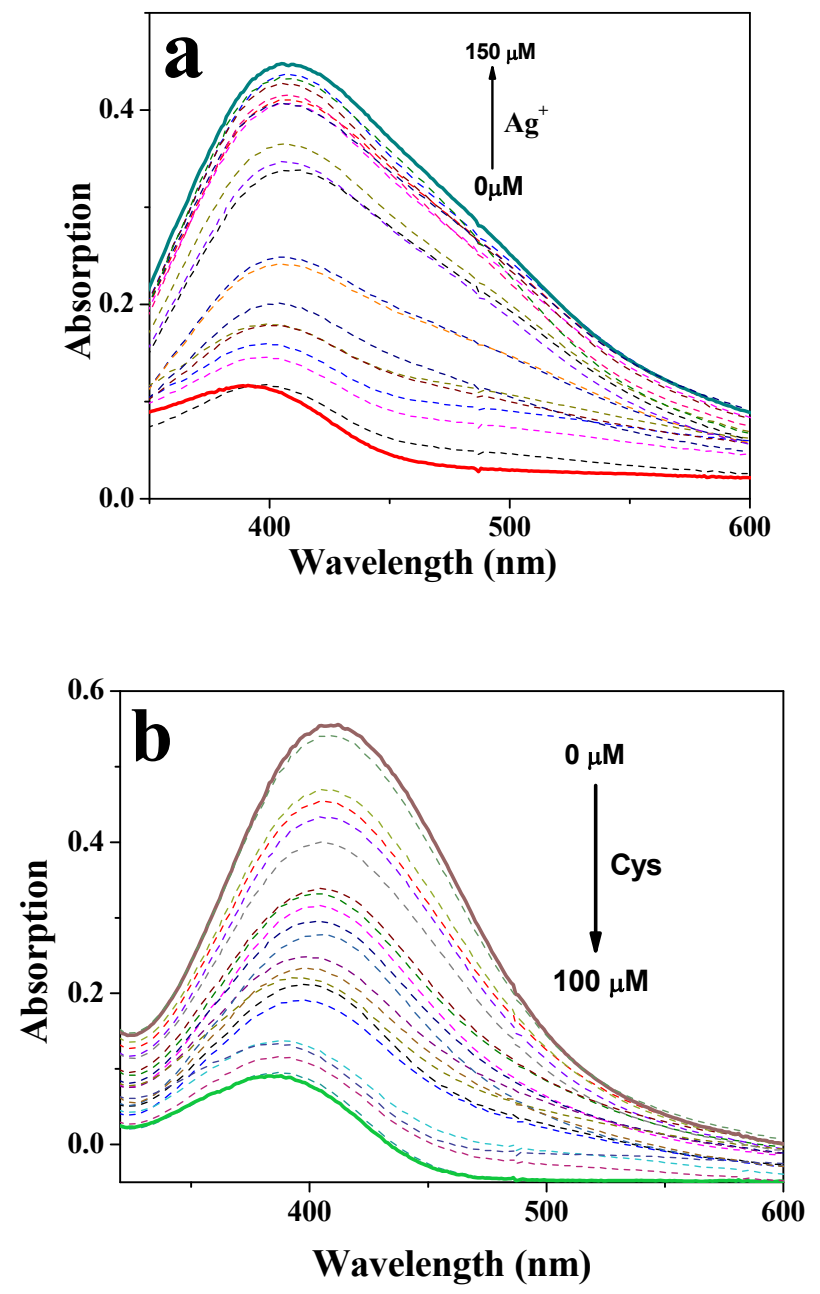

Figure S4 UV-vis absorbance titration spectra of CDs upon addition of a) $\mathrm{Ag}^{+}$ions 1-100 $\mu \mathrm{M}$. b) $\mathrm{CD}-\mathrm{Ag}^{+}$complex with various concentrations of cystine 1-100 $\mu \mathrm{M}$. 


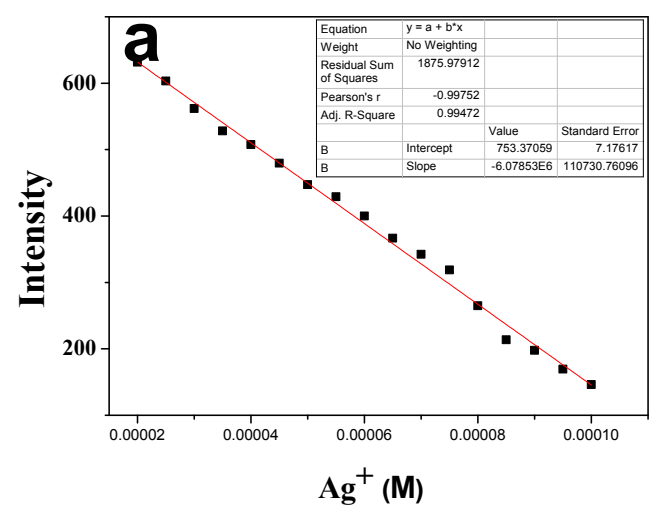

LOD calculation for $\mathrm{Ag}^{+}$

$$
\begin{aligned}
\mathrm{LOD} & =3 \times 0.787 /\left(6.0785 \times 10^{6}\right) \\
& =3.9 \mu \mathrm{M}
\end{aligned}
$$

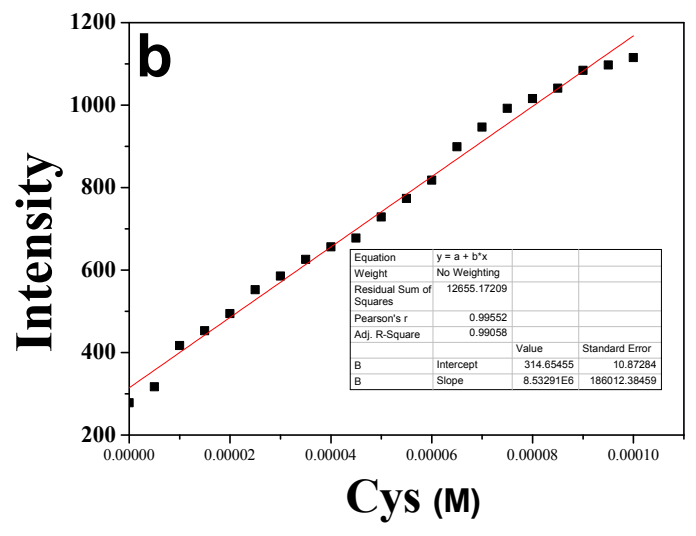

LOD calculation for Cys

$$
\begin{aligned}
\operatorname{LOD} & =3 \times 0.984 /\left(8.532 \times 10^{6}\right) \\
& =3.4 \mu \mathrm{M}
\end{aligned}
$$

Figure S5 Linear calibration plot of CDs with (a) $\mathrm{Ag}^{+}$ions and (b) $\mathrm{CD}-\mathrm{Ag}^{+}$complex with various concentrations of Cys. 

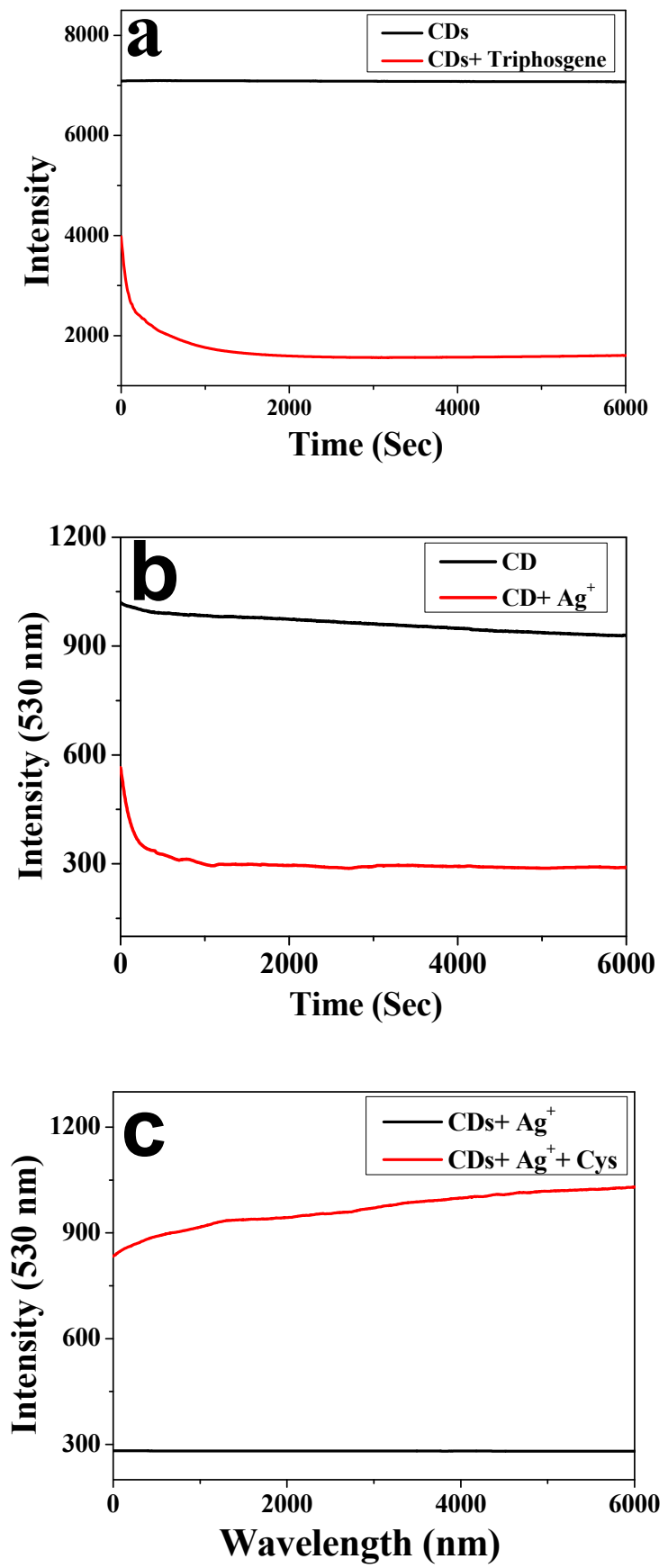

Figure S6 Reaction time profile of CDs with (a) triphosgene $(0-150 \mu \mathrm{M})$. (b) $\mathrm{Ag}^{+}$ions $(1-100$ $\mu \mathrm{M})$. and (c) $\mathrm{CD}-\mathrm{Ag}^{+}$complex with various concentrations of cystine $1-100 \mu \mathrm{M}$. 


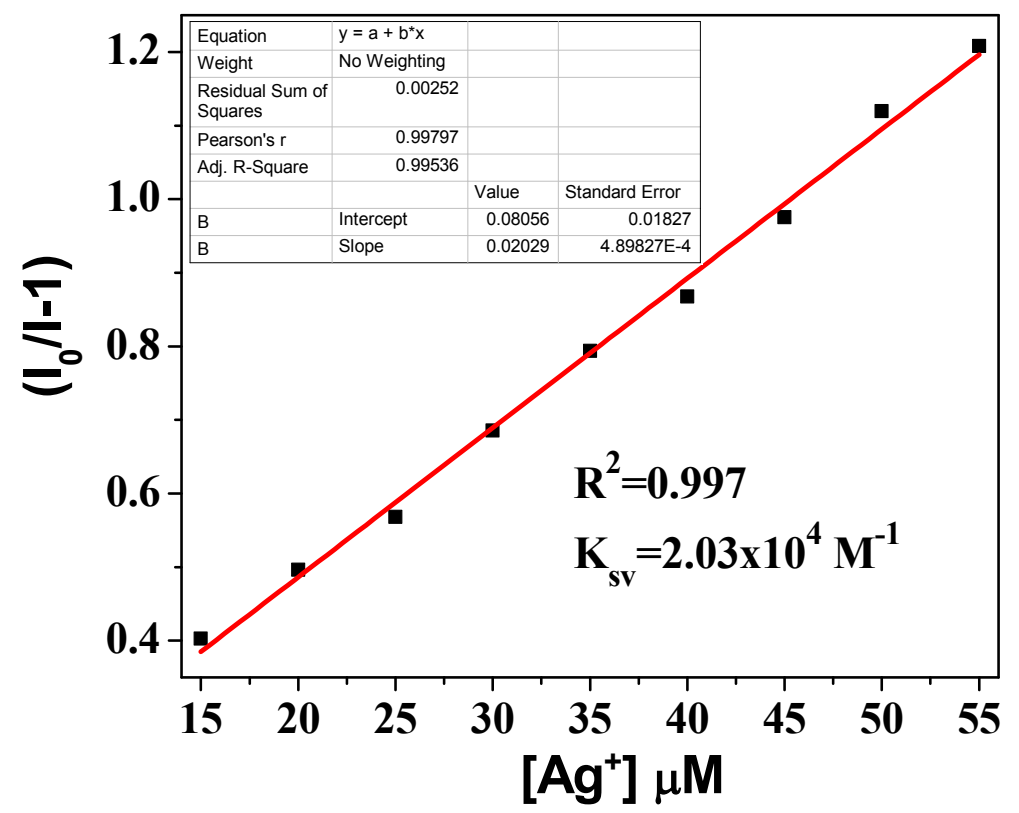

Figure S7 Stern-Volmer plot of CDs in presence of various concentration of $\mathrm{Ag}^{+}$at $\lambda_{\mathrm{em}}=530 \mathrm{~nm}$.

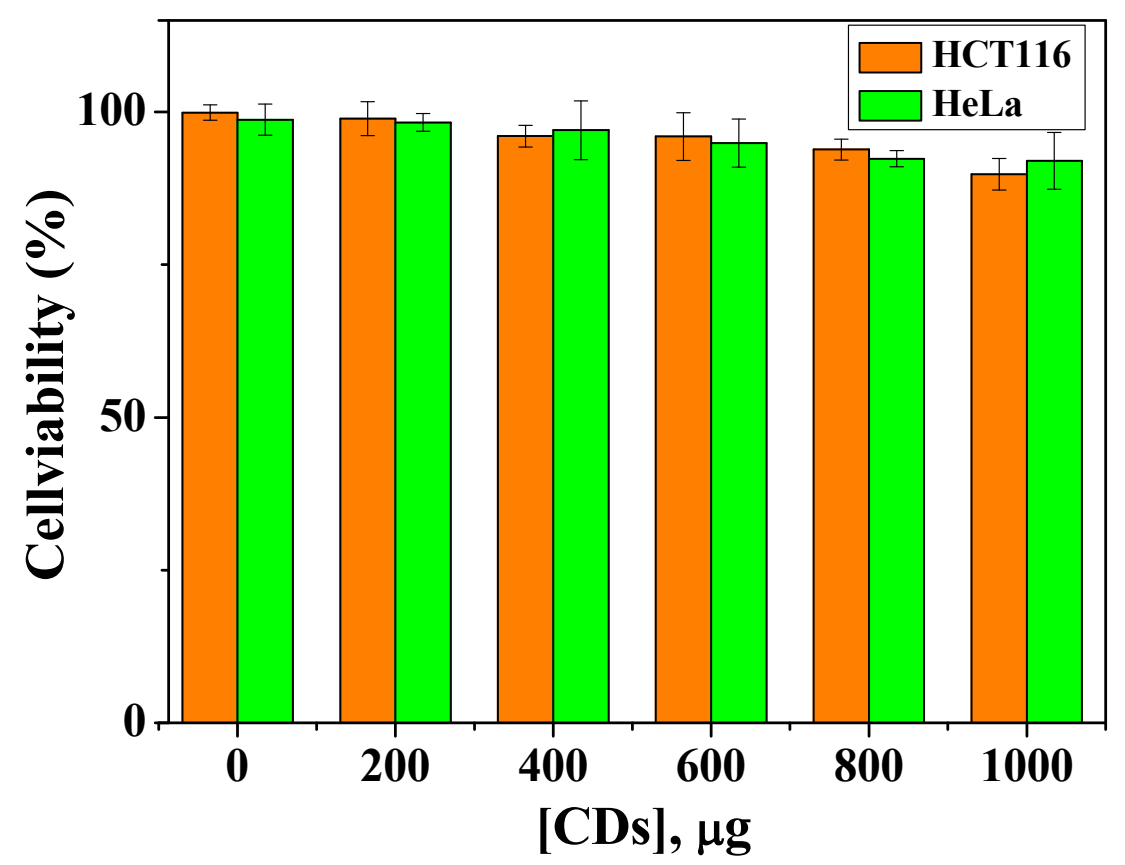

Figure S8 Cellular toxicity of CDs on HCT-116 and HeLa cells. 